\title{
STRUKTUR KOMUNITAS MAKROZOOBENTHOS DI INTERTIDAL BUKIT PIATU - KIJANG, KABUPATEN BINTAN
}

\section{MACROZOOBENTHIC COMMUNITY STRUCTURE AT BUKIT PIATU INTERTIDAL- KIJANG, KABUPATEN BINTAN}

\author{
Lani Puspita \\ Program Studi Pendidikan Biologi, FKIP, Universitas Riau Kepulauan, Batam \\ Korespondensi : lanipuspita@gmail.com
}

\begin{abstract}
Abstrak
Makroozoobenthos adalah salah satu kelompok biota yang umum dijadikan bioindikator kualitas lingkungan. Pada kegiatan penelitian ini, dilakukan pengamatan terhadap struktur komunitas makrozoobenthos di perairan intertidal (pasang surut) Bukit Piatu - Kijang, Kabupaten Bintan. Perairan intertidal yang dijadikan lokasi penelitian merupakan pantai berlumpur yang berada di dekat Dermaga Untuk Kepentingan Sendiri (DUKS) suatu perusahaan tambang granit. Penelitian ini bertujuan untuk mengetahui struktur komunitas makrozoobenthos di perairan intertidal Bukit Piatu - Kijang, Kabupaten Bintan. Di perairan intertidal ini terdapat 3 kelompok makrozoobenthos yaitu Crustacea, Mollusca, dan Polychaeta; dimana spesies-spesies dari kelompok Mollusca mendominasi komunitas makrozoobenthos. Nilai Indeks Keanekaragaman Jenis menunjukkan bahwa komunitas makrozoo-benthos berada pada kondisi sedang/moderat yang mudah berubah dengan berubahnya kondisi lingkungan. Keseragaman jenis makrozoobenthos di pantai sebelah Utara DUKS lebih rendah daripada pantai sebelah Selatan karena pada pantai sebelah Utara terdapat 3 spesies Mollusca yang cukup mendominasi, yaitu Xenoturris spp., Alvania spp., dan Corbula sp.
\end{abstract}

Kata kunci: Struktur komunitas, makrozoobenthos, Bintan

\begin{abstract}
Macrozoobenthic is one of biotas which commonly used as bio-indicator of environmental quality. In this research, an observation on macrozoobenthic community structure was done at Bukit Piatu intertidalKijang, Kabupaten Bintan. Selected intertidal which choden as research siteswere muddy beaches located near Docks For Self Interest (DUKS), a granite mining company. This research aims to know the macrozoobenthic community structure at l Bukit Piatu intertida - Kijang, Kabupaten Bintan. At intertidal there were 3 macrozoobenthic groups, namely Crustacea, Mollusca, and Polychaeta; where the species of the Mollusca group dominated the macrozoobenthic community. The Value of Diversity Index indicated that the macrozoobenthic community was at moderate that was easy changable due to environmental conditions. Uniformity of the macrozoobenthic on the north coast of DUKS was lower than the southern coast because on the north coast there were 3 dominant Mollusca species, namely Xenoturris spp., Alvania spp., And Corbula sp.
\end{abstract}

Keywords: community structure, macrozoobenthic, Bintan

\section{PENDAHULUAN}

Makroozoobenthos adalah salah satu kelompok biota yang umum dijadikan bioindikator kualitas lingkungan. Habitat hidup makrozoo-benthos yang merupakan dasar perairan, serta mobilitasnya yang terbatas dan cenderung sessile (menetap), membuat 
komunitas hewan ini rentan terhadap tekanan lingkungan perairan. Seperti kita ketahui, berbagai jenis bahan pencemar yang terbuang ke laut pada akhirnya akan mengendap ke dasar perairan apabila berat jenisnya lebih besar daripada air laut.

Pada kegiatan penelitian ini, dilakukan pengamatan terhadap struktur komunitas makrozoobenthos di perairan intertidal (pasang surut) Bukit Piatu - Kijang, Kabupaten Bintan. Perairan intertidal yang dijadikan lokasi penelitian merupakan pantai berlumpur yang berada di dekat Dermaga Untuk Kepentingan Sendiri (DUKS) suatu perusahaan tambang granit. Operasional DUKS tambang granit ini diperkirakan dapat mempengaruhi struktur komunitas makrozoobenthos di perairan pesisir tersebut. Dampak terhadap komunitas makrozoobenthos ini dapat terjadi karena adanya pengadukan substrat pantai saat kapal berlabuh serta ceceran minyak dan oli dari kapal.

Kegiatan penelitian ini bertujuan untuk mengetahui struktur komunitas makrozoobenthos di perairan intertidal Bukit Piatu - Kijang, Kabupaten Bintan, yang meliputi keanekaragaman jenis, keseragaman jenis, dan dominansi jenis. Hasil penelitian ini diharapkan dapat menjadi informasi bermanfaat untuk mengetahui pengaruh operasional DUKS terhadap komunitas makrozoobenthos.

\section{METODE PENELITIAN}

\section{Tempat dan Waktu}

Pengambilan sampel makrozoobenthos dilakukan di perairan intertidal sekitar DUKS sebuah perusahaan tambang batu granit di Bukit Piatu - Kijang, Kabupaten Bintan. Pengambilan sampel dilakukan di dua stasiun pengamatan, yaitu: (1) sekitar 10 meter dari sebelah Selatan DUKS dan (2) sekitar 10 meter di sebelah Utara DUKS.

\section{Alat dan Bahan}

Peralatan yang digunakan pada penelitian ini meliputi: pipa paralon PVC berdiameter 2 inchi, kantung sampel plastik, saringan kasar dan halus, kaca pembesar (lup), pinset, cool box, lemari pendingin, tissue, buku identifikasi, dan handy-counter. Sedangkan bahan yang digunakan pada studi ini adalah es.

\section{Metode Pengambilan Sampel}

Pengambilan sampel makrozoobenthos dilakukan dengan mengambil substrat lumpur menggunakan alat sampling berupa pipa paralon PVC berdiameter 2 inchi (luas penampang $=20,2850 \mathrm{~cm}^{2}$ ). Pipa paralon ditancapkan ke dalam substrat lumpur sehingga 
substrat tertahan di dalam paralon, substrat yang tertahan tersebut kemudian dimasukkan ke dalam kantung plastik sampel. Dengan cara seperti ini, makrozoobenthos yang hidup di permukaan substrat (epifauna) dan di dalam substrat (infauna) dapat terambil. Luas area pengamatan di setiap stasiun sampling adalah 10 kali luas penampang pipa paralon atau $202,5802 \mathrm{~cm}^{2}$. Substrat lumpur yang terkumpul dalam kantung plastik kemudian dimasukkan ke dalam cool box untuk kemudian dibawa ke laboratorium.

\section{Metode Analisa Sampel}

Setelah tiba di laboratorium, sampel makrozoobenthos akan dianalisa. Sustrat lumpur yang diambil dari lokasi sampling disaring dengan saringan kasar dan saringan halus. Dengan penyaringan ini, lumpur akan terbuang sedangkan makrozoobenthos yang hidup di dalamnya akan tertahan di permukaan saringan. Setiap makrozoobenhos yang ditemukan kemudian dimasukkan ke dalam wadah plastik dengan pinset. Identifikasi makrozoobenthos dilakukan dengan membandingkan morfologi makrozoobenthos yang ditemukan terhadap panduan yang ada di buku identifikasi. Buku identifikasi yang digunakan adalah The MacDonalds Encyclopedia of Shells (Sabelli, 1991), Periplus Nature Guides Tropical Seashells (Fiene-Severn et. al, 2000), dan Avertebrata Air (Suwignyo et. $a l$, 2005). Untuk membantu pengamatan morfologi makrozoobenthos digunakan kaca pembesar. Jumlah individu makrozoobenthos yang ditemukan untuk setiap spesiesnya kemudian dicatat dan dihitung kepadatan jenisnya. Perhitungan kepadatan jenis dilakukan dengan rumus sebagai berikut:

$$
N_{i}=\frac{n_{i}}{A}
$$

$\mathrm{N}_{\mathrm{i}}=$ kepadatan makrozoobenthos jenis ke-i (individu/ $\mathrm{m}^{2}$ )

$\mathrm{n}_{\mathrm{i}}=$ jumlah individu makrozoobenthos jenis ke-i yang ditemukan (individu)

$\mathrm{A}=$ luas area pengamatan/pengambilan sampel $\left(\mathrm{m}^{2}\right)$, yaitu $0,0203 \mathrm{~m}^{2}$

\section{Metode Analisa Data}

Setelah didapatkan kepadatan masing-masing jenis makrozoobenthos, dilakukan analisa terhadap struktur komunitasnya, yang meliputi keanekaragaman jenis, keseragaman jenis, dan dominansi jenis (Basmi, 2000; Odum, 1997).

$\underline{\text { Keanekaragaman Jenis }}$

Keanekaragaman jenis dihitung dengan menghitung Indeks Keanekaragaman Jenis Shannon - Wienner (H'). Rumusnya adalah sebagai berikut: 


$$
H^{\prime}=\sum\left(\frac{N_{i}}{N_{\text {total }}} \bullet \log _{2} \frac{N_{i}}{N_{\text {total }}}\right)
$$

$\mathrm{H}^{\prime} \quad=$ Indeks Keanekaragaman Jenis Shannon - Wienner

$\mathrm{N}_{\mathrm{i}}=$ kepadatan makrozoobenthos jenis ke-i (individu $/ \mathrm{m}^{2}$ )

$\mathrm{N}_{\text {total }}=$ kepadatan seluruh jenis makrozoobenthos yang teridentifikasi (individu $/ \mathrm{m}^{2}$ )

$\log _{2}=$ logaritma basis 2

Kisaran nilai:

$0 \leq \mathrm{H}^{\prime}<1$ tingkat keanekaragaman jenis rendah

$1 \leq \mathrm{H}^{\prime}<3$ tingkat keanekaragaman jenis sedang

$\mathrm{H}^{\prime} \geq 3 \quad$ tingkat keanekaragaman jenis tinggi

\section{Keseragaman Jenis}

Keseragaman jenis dihitung dengan menghitung Indeks Keseragaman Jenis Evenness

(E). Rumusnya adalah sebagai berikut:

$$
E=\frac{H^{\prime}}{\ln S}
$$

$\mathrm{E} \quad=$ Indeks Keseragaman Evenness

H' = Indeks keanekaragaman Shannon - Wienner

$\log _{2} \quad=$ logaritma basis 2

$\mathrm{S} \quad=$ jumlah species makrozoobenthos yang ditemukan

Kisaran nilai:

$0 \leq \mathrm{E}<0,3 \quad$ tingkat keseragaman jenis rendah

$0,3 \leq \mathrm{E}<0,6$ tingkat keseragaman jenis sedang

$\mathrm{E} \geq 0,6 \quad$ tingkat keseragaman jenis tinggi

\section{Dominansi Jenis}

Dominansi jenis dihitung dengan menghitung Indeks Dominansi Simpson. Rumusnya adalah sebagai berikut:

$$
D=\sum\left(\frac{N_{i}}{N_{\text {total }}}\right)^{2}
$$

$\mathrm{D} \quad=$ indeks dominansi simpson

$\mathrm{N}_{\mathrm{i}} \quad$ = kepadatan makrozoobenthos jenis ke-i (individu $/ \mathrm{m}^{2}$ )

$\mathrm{N}_{\text {total }}=$ kelimpahan seluruh jenis makrozoobenthos yang teridentifikasi (individu $/ \mathrm{m}^{2}$ )

Kisaran nilai:

$0 \leq \mathrm{D}<0,3 \quad$ tingkat dominansi jenis rendah

$0,3 \leq \mathrm{D}<0,6 \quad$ tingkat dominansi jenis sedang

$\mathrm{D} \geq 0,6 \quad$ tingkat dominansi jenis tinggi 


\section{HASIL DAN PEMBAHASAN}

Hasil perhitungan kepadatan dan indeks struktur komunitas makrozoobenthos disajikan pada Tabel 1. Pengambilan sampel makrozoobenthos dilakukan di perairan intertidal (pantai berlumpur) sekitar DUKS; Stasiun 1 terletak \pm 10 meter di sebelah Selatan DUKS, sedangkan Stasiun 2 terletak \pm 10 meter di sebelah Utara DUKS.

Tabel 1. Kepadatan dan Struktur Komunitas Makrozoobenthos

\begin{tabular}{|c|c|c|c|}
\hline \multirow{2}{*}{ NO. } & \multirow{2}{*}{ Spesies } & \multicolumn{2}{|c|}{ Kepadatan (Individu/m²) } \\
\hline & & Stasiun 1 & Stasiun 2 \\
\hline & CRUSTACEA & & \\
\hline 1. & Scylla serrata & - & 49 \\
\hline 2. & Penaeus sp. & 49 & - \\
\hline \multirow[t]{2}{*}{3.} & Eupagurus sp. & 247 & - \\
\hline & MOLLUSCA & & \\
\hline 4 & Corbula sp. & 790 & 592 \\
\hline 5. & Mytilus sp. & - & 49 \\
\hline 6. & Penicillus australis & - & 49 \\
\hline 7. & Triphora sp. & - & 49 \\
\hline 8. & Viriola sp. & - & 99 \\
\hline 9. & Xenoturris spp. & 3752 & 691 \\
\hline 10. & Alvania spp. & 1432 & 889 \\
\hline 11. & Strombus sp. & 49 & 148 \\
\hline 12. & Janthina janthina & - & 49 \\
\hline 13. & Turitella $\mathrm{sp}$. & 99 & - \\
\hline 14. & Urosalpinx cinera & 99 & - \\
\hline \multirow[t]{2}{*}{15.} & Mya sp. & 49 & - \\
\hline & POLYCHAETA & & \\
\hline \multirow[t]{6}{*}{16.} & Nereis sp. & 247 & 148 \\
\hline & Jumlah Individu & 6812 & 2814 \\
\hline & Jumlah Taxa & 10 & 11 \\
\hline & Indeks Keanekaragaman (H') & 1,9858 & 2,6242 \\
\hline & Indeks Keseragaman (E) & 0,5978 & 0,7585 \\
\hline & Indeks Dominansi (D) & 0,3641 & 0,2126 \\
\hline
\end{tabular}

Keterangan:

Stasiun 1 : Perairan dermaga khusus, jarak 10 meter di sebelah Selatan DUKS

Stasiun 2 : Perairan dermaga khusus, jarak 10 meter di sebelah Utara DUKS

Pada Tabel 1 dapat kita lihat bahwa makroozoobenthos yang ditemukan di Stasiun 1 dan 2 terdiri dari 3 filum, yaitu: Crustacea, Mollusca, dan Polychaeta. Menurut Nybakken (1992), kelompok makrofauna yang dominan di daerah pantai berlumpur dan berpasir adalah cacing Polychaeta, Mollusca, serta Crustacea kecil dan besar. Pada pantai 
berlumpur terdapat banyak bahan organik, baik dalam endapan lumpur maupun yang tersuspensi di kolom air saat pasang, karena itu tipe cara makan yang dominan di pantai berlumpur adalah pemakan deposit (deposit feeder) dan pemakan bahan melayang (suspension feeder). Mollusca (Gastropoda dan Bivalvia), beberapa jenis Crustacea, dan beberapa jenis Polychaeta merupakan pemakan bahan tersuspensi. Sejumlah besar Polychaeta lain merupakan pemakan deposit; mereka menggali substrat, mencerna dan menyerap bahan organik (atau bakteri), dan mengeluarkan bahan yang tidak dicerna melalui anus.

Jumlah spesies makrozoobenthos yang ditemukan di Stasiun 1 dan Stasiun 2 tidak berbeda jauh; Stasiun 1 memiliki 10 spesies makrozoobenthos (2 spesies Crustacea, 7 spesies Mollusca, dan 1 spesies Polychaeta), sedangkan Stasiun 2 memiliki 11 spesies makrozoobenthos (1 spesies Crustacea, 9 spesies Mollusca, dan 1 spesies Polychaeta). Walaupun jumlah spesies antara kedua stasiun pengamatan tidak jauh berbeda, namun kepadatan makrozoobenthos pada Stasiun 1 lebih tinggi daripada Stasiun 2; pada Stasiun 1 kepadatan makrozoobenthos adalah 6.812 individu/m² sedangkan pada Stasiun 2 adalah 2.814 individu $/ \mathrm{m}^{2}$. Lebih padatnya makrozoobenthos pada Stasiun 1 dikarenakan lebih luasnya dataran lumpur pada daerah tersebut, sedangkan pada Stasiun 2 sebagian pantai bersubstrat pasir. Menurut Nybakken (1992), pantai bersubstrat lumpur lebih produktif daripada pantai bersubstrat pasir karena pada substrat lumpur terakumulasi lebih banyak bahan organik.

Di kedua stasiun pengamatan, keanekaragaman jenis makrozoobenthos tergolong sedang/moderat (nilai indeks berada pada kisaran $1-3$ ). Komunitas dengan keanekaragaman jenis yang moderat mudah berubah hanya dengan mengalami perubahan lingkungan yang relatif kecil. Apabila terjadi peningkatan bahan pencemar, maka akan terjadi perubahan struktur komunitas yang ekstrim yang mengarah kepada Indeks Keanekaragaman yang rendah $\left(H^{\prime}<1\right)$. Sebaliknya, apabila jumlah bahan pencemar yang masuk ke dalam perairan sedikit dan jumlah bahan makanan mencukupi, maka nilai Indeks Keanekaragaman Jenis dapat lebih tinggi dari semula (Basmi, 2000).

Jika kita bandingkan besarnya nilai Indeks Keanekaragaman Jenis antara Stasiun 1 dan 2, dapat kita lihat bahwa Stasiun 2 memiliki keanekaragaman jenis yang sedikit lebih tinggi (hal ini sejalan dengan jumlah taxa yang sedikit lebih tinggi daripada Stasiun 1). Lebih tingginya keanekaragaman jenis pada Stasiun 2 dapat disebabkan karena pada lokasi 
tersebut sebetulnya terjadi peralihan antara pantai berlumpur dan pantai berpasir, sehingga spesies-spesies yang ditemukan stasiun pengamatan ini meliputi spesies dari kedua jenis pantai. Menurut Nybakken (1992), garis batas antara pantai berpasir dan berlumpur tidaklah terlalu jelas. Pantai berpasir mempunyai ukuran butiran yang lebih besar dan pantai berlumpur mempunyai ukuran butiran yang halus. Pantai berlumpur merupakan bentuk lanjutan dari pantai berpasir dalam suatu gradien pantai yang terbentuk akibat meningkatnya perlindungan terhadap gerakan gelombang. Oleh karena itu kedua jenis pantai ini memiliki kelompok makrofauna dominan yang sama (yaitu Polychaeta, Mollusca, dan Crustacea) tetapi dengan jenis yang berbeda.

Ditinjau dari nilai Indeks Keseragaman Jenisnya, keseragaman jenis makrozoobenthos pada Stasiun 1 tergolong sedang namun memiliki kecenderungan ke tinggi (nilai indeks hampir mendekati 0,6), sedangkan keseragaman jenis makrozoobenthos pada Stasiun 2 tergolong tinggi (nilai indeks $\geq 0,6$ ). Indeks Keseragaman Jenis menggambarkan jumlah individu pada masing-masing spesies, apabila jumlah individu pada masing-masing spesies relatif sama (perbedaannya tidak mencolok) maka nilai indeks akan mendekati 1 (Basmi 2000; Odum 1998). Pada Stasiun 1 terdapat 3 spesies yang jumlahnya jauh lebih banyak, yaitu Xenoturris spp. (jumlahnya 3.752 individu/ $\mathrm{m}^{2}$ atau $55,08 \%$ dari keseluruhan makrozoobenthos), Alvania spp. (jumlahnya 1.432 individu/m² atau $21,02 \%$ dari keseluruhan makrozoobenthos), dan Corbula sp. (jumlahnya 790 individu/ $\mathrm{m}^{2}$ atau $11,60 \%$ dari keseluruhan makrozoobenthos).

Hasil perhitungan Indeks Keseragaman Jenis sejalan dengan hasil perhitungan Indeks Dominansi Jenis. Pada Stasiun 1 nilai Indeks Dominansi jenis tergolong sedang $(0,3$ $\leq \mathrm{D}<0,6)$, sedangkan pada Stasiun 2 nilai Indeks Dominansi jenis tergolong rendah $(0 \leq \mathrm{D}$ $<0,3)$. Spesies yang mendominansi pada Stasiun 1 adalah Xenoturris spp., Alvania spp., dan Corbula sp. (ketiganya merupakan Mollusca kecil yang berukuran kurang dari 1,5 inchi; Xenoturris dan Alvania merupakan gastropoda sedangkan Corbula merupakan bivalvia).

\section{KESIMPULAN}

Perairan intertidal di sekitar DUKS perusahaan granit di Bukit Piatu - Kijang, Kabupaten Bintan merupakan pantai yang memiliki makrozoobenthos cukup padat. Daerah di sebelah Utara DUKS memiliki kepadatan makrozoobenthos lebih tinggi karena 
pantainya memiliki dataran lumpur lebih luas; sedangkan daerah di sebelah Selatan DUKS memiliki kepadatan makrozoobenthos lebih rendah karena pantainya merupakan peralihan antara pantai berpasir dan berlumpur. Di perairan intertidal ini terdapat 3 kelompok makrozoobenthos yaitu Crustacea, Mollusca, dan Polychaeta; dimana spesies-spesies dari kelompok Mollusca mendominasi komunitas makrozoobenthos. Nilai Indeks Keanekaragaman Jenis menunjukkan bahwa komunitas makrozoo-benthos berada pada kondisi sedang/moderat yang mudah berubah dengan berubahnya kondisi lingkungan. Keseragaman jenis makrozoo-benthos di pantai sebelah Utara DUKS lebih rendah daripada pantai sebelah Selatan karena pada pantai sebelah Utara terdapat 3 spesies Mollusca yang cukup mendominasi, yaitu Xenoturris spp., Alvania spp., dan Corbula sp.

\section{REFERENSI}

Fiene-Severn, P, M. Severn, and R. Dyerly. 2000. Periplus Nature Guides Tropical Seashells. Periplus Editon (HK) Ltd. Singapore.

Nybakken, J. W. 1992. Biologi Laut: Suatu Pendekatan Ekologis. PT. Gramedia Pustaka Utama. Jakarta.

Odum, E. P. 1998. Dasar-Dasar Ekologi. Gadjah Mada University Press. Jogjakarta.

Sabelli, B. 1991. The MacDonalds Encyclopedia of Shells. MacDonalds \& Co (Publisher) Ltd. Toledo, S.A - Spain.

Suwignyo, S., B. Widigdo, Y. Wardiatno, dan M. Krisanti. 2005. Avertebrata Air, Jilid 1. Penebar Swadaya. Depok.

Suwignyo, S., B. Widigdo, Y. Wardiatno, dan M. Krisanti. 2005. Avertebrata Air, Jilid 2. Penebar Swadaya. Depok. 